\title{
Př́spěvek k pojetí jazyka u Francise Bacona a Jana Amose Komenského III
}

\author{
A Study in LANGUAGE ANALYSIS Of FRANCIS BACON AND JOHAN AMOS COMENIUS III: \\ BACON, COMENIUS AND THEIR LEGACY IN SWIFT AND SHERIDAN
}

\section{Jitka Kuncová 1}

Abstrakt: Článek představuje třetí a závěrečnou část série, která je věnována analýze chápání jazyka ve vybraných dílech Francise Bacona a Jana Amose Komenského. Pokouší se uplatnit srovnávací prístup, díky němuž nechá vystoupit specifické jednotě a diferenci přístupů a z nich vyplývajících závěrů zkoumaných myslitelů. $V$ druhé části práce budeme sledovat přinejmenším implicitní vliv Baconova ideálu „učené společnosti“ na Swiftovu vizi reformy a nápravy anglického jazyka cestou ustavení akademie. Závěrečná část práce přináší nová zjištění o překvapivé podobnosti Komenského přístupu jazyku s přístupem Dr. Thomase Sheridana, ředitele reformované školy, filosofa a jazykovědce z Dublinu první třetiny 18. století, jehož Jonathan Swift nazývá „druhým Šalamounem“ a považuje za největšího soudobého učitele.

Klíčová slova: Francis Bacon, Jan Amos Komenský, Thomas Sheridan, Jonathan Swift, filosofie jazyka, reforma vzdělání, teologie.

Abstract: Presented paper is considered as the third and final part of a series dedicated to understanding of language in selected works of Francis Bacon and Johannes Amos Comenius. The first section is of a comparative nature followed by the second section on Swift's idea of an academy for the reform/correction of English language reflecting at least indirect influence of Bacon's idea of learned society. Final section is dedicated to a new observation about similarity of late Comenius' ideas of Latin college with the ones of $\mathrm{Dr}$ Thomas Sheridan, the 18th century Irish schoolmaster, philosopher and linguist from Dublin, entitled "the second Solomon" by Jonathan Swift.

Keywords: Francis Bacon, Johan Amos Comenius, Thomas Sheridan, Jonathan Swift, philosophy of language, education, theology.

\footnotetext{
${ }^{1}$ Katedra německého jazyka, Fakulta mezinárodních vztahů, Vysoká škola ekonomická v Praze, nám. W. Churchilla 4, 13067 Praha 3, jitka.kuncova@vse.cz
} 


\section{Bacon, Komenský a ozvuky jejich pojetí jazyka u Swifta a Sheridana}

V třetí a závěrečné části studie se pokusíme v prvním kroku zrekapitulovat výsledky analýzy př́stupů k jazyku, jak o nich podaly svědectví texty, které jsme zvolili. Jistě tak nezískáme vyčerpávající obraz věci, předmětem našeho zkoumání nebyl a ani s ohledem na formát studie ani nemohl být celek díla Francise Bacona a Jana Amose Komenského. Na druhé straně jsme však mohli vidět, že i ona orientace na detail přináší nezanedbatelné svědectví o podobnosti i diferenci akcentů $\mathrm{v}$ př́stupech zmiňovaných autorů $\mathrm{k}$ jazyku, a snad se nám podaří v následujících krocích studie ukázat, že tyto př́stupy mají i svoji heuristickou plodnost a rozhodně nezůstávají bez odezvy.

Druhá a třetí kapitola studie nás již přenesou ze 17. do 18. století a pokusíme se ukázat na př́kladech idejí ale i praktických pokusů dvou vzdělanců tematizujících jazyk, že Baconovy a Komenského myšlenky se stávají čímsi až dobově samožrejmým, ale zároveň jsou specificky kultivovány, aniž by přitom jejich původ byl vždy uvědomován. Pestré realizační podoby zkoumání jazyka, ale i pokusů o jeho reformu v 18. století si uvedeme na prríkladech Jonathana Swifta a Thomase Sheridana staršího. Budou to (nejen) ilustrativní setkání, která zprostředkují pro naši akademickou obec první dotek s myšlením doposud v daném kontextu prakticky neznámých postav, ale měla by připravit půdu pro další studii či studie, orientované na detailní rozbory cest zkoumání jazyka a jeho původu, a to zejména v epoše osvícenství.

Ve druhém kapitole tak budeme sledovat přinejmenším implicitní vliv Francise Bacona na Swiftovu ideu reformy a nápravy anglického jazyka cestou založení učené společnosti, akademie. Výklad postavíme na analýze dvou pramenů, a to jednak 'A Proposal for Correcting, Improving, and Ascertaining, the English Tongue' ${ }^{2}$, jednak 'An Essay on Modern Education' ${ }^{3}$, kde je na Bacona explicitně odkazováno. Zohledníme rovněž dva významné zdroje interpretace Swiftova myšlenkového odkazu, které jsou pro naše sledované téma relevantní. Jsou jimi článek J. H. Neumanna 'Jonathan Swift and English Pronunciation'4 a kapitola zabývající se Swiftovou ideou reformy a nápravy anglického jazyka v nejrozsáhlejší kritické biografii a analýze díla Jonthana Swifta od Irvina Ehrenpreise. ${ }^{5}$

Závěrečná kapitola pak přináší i jistá nová zjištění o podobnosti Komenského přístupu k jazyku v díle Nové Latium s př́stupem Dr. Thomase Sheridana, ředitele reformované školy, filosofa a jazykovědce z Dublinu první třetiny 18. století, jehož Jonathan Swift nazývá „druhým Šalamounem“ a považuje jej za největšího soudobého učitele nejen v Irsku, ale i v Anglii či Skotsku. Evidence o blízkosti Sheridanovy školy či akademie a Komenského ideálu Nového Latia však bude jen nepř́má, nedochovaly se rukopisy vztahující se k Sheridanově škole, při

2 J. Swift, 'A Proposal for Correcting, Improving, and Ascertaining, the English Tongue', in The Works of Jonathan Swift, D.D. by Sir Walter Scott, Second edition, Volume IX, Edinburgh, 1824, s. 137- 159.

${ }^{3}$ J. Swift, 'An Essay on Modern Education', in The Works of Jonathan Swift, D.D. by Sir Walter Scott, Second edition, Volume IX, Edinburgh, 1824, s. 160 - 170.

4 J. H. Neumann, 'Jonathan Swift and English Pronunciation', in Quarterly Journal of Speech, Volume 28, 1942 - Issue 2, pp. 198 - 201 (Published online: 05 June 2009, https://doi.org/10.1080/00335634209380757).

${ }^{5}$ I. Ehrenpreis, Swift: The Man, his Works, And the Age, Volume 2, Methuen: 1982 (1967), pp. 542 549. 
výkladu tedy budeme vycházet z dobových pramenů, a to zejména díla Jonathana Swifta ${ }^{6}$, který na Sheridanově škole dokonce několikrát působil jako examinátor a Sheridan proň byl jedním z nejbližších přátel konce druhého desetiletí a 30. let 18. století v Dublinu, dále pak jediného relevantního sekundárního zdroje představujícího ideál i realizaci Sheridanovy školy ${ }^{7}$ a dalších převážně biografických zdrojů jako je Oxford Dictionary of National Biography. ${ }^{8}$

\subsection{Bacon a Komenský: jazyk, cesty obnovy vědění a nová škola}

V první studii našeho cyklu ${ }^{9}$ jsme se pokusili cestou pozorné četby Baconova díla nechat opatrně vystoupit tři pasáže textu, kde se podle našeho soudu vyskytuje motiv jazyka, a to vždy ve specifickém kontextu a zároveň v různých významových rovinách. Motivy jazyka jsme odvodili z textové evidence, a to jak českého překladu Aloise Bejblíka (opírá se o anglický překlad ve variantě vydání nakladatelství Routledge v Londýně z roku 1905), ${ }^{10}$ tak prvního v pravdě kritického překladu latinského originálu do anglického jazyka z roku 1733. ${ }^{11}$

Naši cestu včetně jejich mezí jsme ukázali v kontextu s aktuálním výzkumným projektem Warburgova institutu v Londýně, který uspořádal v roce 2013 konferenci se záměrem explikovat specifické roviny Baconova pojetí jazyka. V obsáhlé poznámce 9 jsme citovali závěry týkající se identifikace těchto rovin: „, metaphysical (the alphabet of the original desires of matter), epistemological (patterns of communication in experimental settings), rhetorical (strategies of persuasion in ethical, political and religious situations), grammatical (grammar as the antidote to postlapsarian obfuscation and post-Babelic fragmentation), multilingual (the relationship between Latin and the vernacular), emblematic (the relationship between verbal and visual thinking) and stylistic (the art of writing and the appropriate choice of literary genres). “12

Z prostého výčtu rovin a v konfrontaci s motivy zachycenými v naší práci se nám ukázalo, že Nová Atlantida není dílem, které nám umožní zakusit všechny výše uvedené roviny, ale specificky akcentuje rovinu biblickou, gramatickou a neméně specificky orientovanou rovinu epistemologickou, a to v kontextu s teologickým vyladěním celku díla, které přináší vizi společenství soustředěného kolem odhalování jazyka, gramatiky Stvoření, včetně jeho institucionální báze. Nová Atlantida nám tak poskytnula překvapivě mnoho podnětů k novému promýšlení vztahu filosofie, vědy (včetně jazykovědy) a teologie v epoše raného novověku.

\footnotetext{
$6 \mathrm{~J}$. Swift, 'Character of Dr. Sheridan', in The Works of Jonathan Swift, D.D. by Sir Walter Scott, Second edition, Volume IX, Edinburgh, 1824, s. 310-313.
}

J. Swift, 'The History of the Second Solomon', in The Works of Jonathan Swift, D.D. by Sir Walter Scott, Second edition, Volume IX, Edinburgh, 1824, s. $314-321$.

${ }^{7}$ R. E. Ward, An Encyklopedia of Irish Schools, 1500 - 1800, Lampeter : Edwin Mellen Press, 1995.

8 W. R. Meyer, 'Thomas Sheridan (1687-1738)', in Oxford Dictionary of National Biography, Volume 50, Oxford: Oxford University Press, 2004, s. $305-306$.

${ }^{9} \mathrm{~J}$. Kuncová, 'Príspěvek $k$ pojetí jazyka u Francise Bacona a Jana Amose Komenského I', E-Logos (2013).

${ }^{10}$ F. Bacon, Nové organon, Praha: Česká akademie věd a umění, 1922 (překl. Č. Stehlík a A. Stejskal).

${ }^{11}$ F. Bacon, The New Atlantis: or a Plan of a Society for the Promotion of Knowledge in The Philosophical Works of Francis Bacon, In Three Volumes, Vol. I., ed. P. Shaw, London: Printed for J. J. and P. Knapton, 1733, s. $278-300$.

12 http://warburg.sas.ac.uk/events/colloquia/bacon-on-languages/ 
V první části studie (1.1 Znalost jazyků) jsme přinejmenším implicitně nechali vystoupit tu rovinu pojetí jazyka u Bacona, která je vymezována jako „multilingual (the relationship between Latin and the vernacular)“. Zahládli jsme ji v Baconově líčení, kdy ostrované vyslali člun, ,jeden z nich držel v ruce velkou bambusovou hůl, na obou koncích modře zdobenou, a ten vystoupil na naši palubu, aniž jevil sebemenší známky strachu. Když viděl, že jeden z nás před něj poněkud ze skupiny vystoupil, vytáhl malý svitek pergamenu (byl o něco žlutší než náš a měl stejný lesk jako stránky v našich zápisových foliantech, byt' byl současně měkký a ohebný) a podal jej našemu předákovi. Na svitku - ve staré hebrejštině, ve staré rěctině, v dobré školské latině a španělštině (proložila J.K. dle originálu) - stála tato slova ..."13 Poslední věta v originále zní ,a little Scroll of yellow polish'd Parchment, wherein were written in ancient Hebrew, ancient Greek, Latin of the School, and in Spanish ..." ${ }^{14}$ Bezprostřední vstup na pevninu byl odmítnut, cizinci jsou zklamáni, „na druhé straně však poznání, že jsou tito lidé znalí jazyků a plní slitovnosti, nás nemálo utěšilo. Nade vše pak jsme se radovali ze znamení křiže, který pro nás byl předzvěstí, že se přece jen můžeme nadít něčeho dobrého. Odpověděli jsme jim ve španělské řeči..." (proložila - J.K.). ${ }^{15}$ V této souvislosti jsme upozornili, že ve vydání z roku 1733, pasáž o chvále znalosti jazyků na straně ostrovanů a radosti ze znamení kříže schází, zůstalo pouhé „Our Answer was, in Spanish.“16

Druhá část první studie (1.2 Zázraky, cizí jazyky a ochrana před bezvěrectvím) pak přináší textovou evidenci, jež není přímo zařaditelná do žádné $\mathrm{z}$ výše uvedených rovin, $\mathrm{v}$ jistých ohledech se snad blíží rovině vymezené jako ,grammatical (grammar as the antidote to postlapsarian obfuscation and post-Babelic fragmentation)“" a specificky se prolíná i s rovinou multilinguální. Relevantní část líčení začíná na místě, kde správce vykládá cizincům o dějinách ostrovní společnosti, kdy tato byla obdařena zkušeností hned se dvěma zázraky (a právě onen druhý se bude vztahovat k našemu tématu), které samu společnost a její misi přinejmenším spolu-legitimizují jako realizaci v mezích lidských schopností dosažitelného ideálu. Shledali jsme, že ve vztahu ke sledovanému motivu jsou relevantní odstavce 18 - 22, vycházeli jsme přitom z vydání z roku 1733, kde jsou jednotlivé odstavce číslovány a u každého odstavce je uvedena anotace, $v$ níž Bacon jednou větou popisuje to, o čem př́slušný odstavec pojednává. ${ }^{17}$ Explicitně se k našemu tématu vztahuje odstavec 22. A Farther Miracle, both in the Book and Letter. ${ }^{18}$ Ten př́mo hovoří o ,zázraku podobného daru cizích jazyků apoštolům“ a není pochyb o tom, že tento „zázrak“ má konstitutivní význam pro založení a udržení „Šalamounovy koleje“ či „Koleje šesti dnů“, tedy samotného kořenu mise křest’anského společenství na Ostrově a zároveň představy mohutně inspirující $\mathrm{k}$ založení a provozu učených společností podporující experimentální praxi nejen v Anglii 17. století. V tomto kontextu je př́značná ona modlitba jednoho z výzkumníků Šalamounova domu, která přináší snad nejpřsesvědčivější svědectví o tom, jak Baconem specificky orientovaná „experimentální věda“ rozumí své fundaci a svému poslání. ${ }^{19}$

\footnotetext{
${ }^{13}$ F. Bacon, Nová Atlantida a Eseje, s. 9- 10.

${ }^{14}$ F. Bacon, The New Atlantis, s. 278- 279.

15 F. Bacon, Nová Atlantida a Eseje, s. 10.

${ }^{16}$ F. Bacon, The New Atlantis, s. 279.

17 Pro úplnost dodejme, že anglické vydání z roku 1733 rozděluje dílo na dvě části, kdy první část obnáší celkem 35 odstavců. Níže uvedené číslování odstavců v paragrafu 1.2 se tedy vztahuje $k 1$. části díla, od paragrafu 1.3 bude číslováni odstavců vztaženo $k$ druhé části díla.
}

${ }^{18}$ F. Bacon, The New Atlantis, s. 284.

${ }^{19}$ F. Bacon, Nová Atlantida a Eseje, s. 16 - 17. 
Třetí část první studie (1.3 Čteme knihu přírody či stvoření a jsme tlumočníci (mise Šalamounova domu či Koleje díla šesti dnů) nám v jistém smyslu pomohla při hledání té roviny Baconova rozumění jazyku, která je označována jako rovina první, metafyzická („,metaphysical (the alphabet of the original desires of matter)"). To jsme však tvrdili s velkou opatrností, vykládána je totiž organizace, činnosti a funkce výzkumníků, záležitosti, které se ukázaly v mnoha ohledech jako nezbytné pro to, aby se nám mohla ukázat. S jistým oprávněním se tedy můžeme odvážit tvrdit, že oné metafyzické rovině mají nejblíže právě ti, kdo jsou vykonavateli funkce Tlumočníků Přírody. Ti by však knihu př́rody a stvoření nikdy nepřečetli a neinterpretovali sami, bez spolupráce s dalšími „fellows“, bez návaznosti na tvrdou experimentální práci a systematický popis jevů př́rody svých kolegů z Koleje díla šesti dnů. I v rámci našeho shrnutí je důležité si připomenout, že „založení a vytvoření Řádu neboli Společnosti, již nazýváme Šalamounův di̊m; je to (jak se domníváme) nejznamenitější zařízení, jaké kdy na světě bylo; je to maják tohoto království. Věnuje se studiu výtvorů a tvorů božích." ${ }^{20}$ Nebudeme zde znovu rekapitulovat detaily výzkumné organizace Šalamounova domu, nicméně nemůžeme pominout „velké finále“, kde se motiv jazyka ukazuje ve své síle a specifickém zabarvení. Na samotném vrcholu, jímž se živý a neustále obnovovaný výzkumný cyklus vědecké práce Šalamounova domu uzavírá, aby získal další směr potenciálně nevyčerpatelného pokračování, se setkáváme s trojící badatelů, kteří „zobecňují předchozí experimenty a poznatky, kladou je do širších souvislostí a vyvozují z nich axiómy a poučky. Ř́káme jim Tlumočníci Př́rody.“ ${ }^{21}$ Vědecká práce Šalamounova domu kulminuje úsilím porozumět knize a řeči přírody či stvoření, snažme se být dobrými tlumočníky, obnovme ,jazyk vědy“ tím, že se staneme tlumočníky skrývajícího se jazyka př́rody a stvoření. Ve 2. části práce (Swiftova idea akademie pro reformu a nápravu anglického jazyka) přineseme alespoň skromnou evidenci o tom, že Baconova idea „Šalamounova domu“ inspirující vznik učených společností a výzkumných institucí, se specificky uplatnila v oblasti zkoumání jazyka, začala žít „vlastním životem“ a zároveň s tím pozbyla explicitní teologické zakotvení.

V první části druhého článku² (2.1 Baconovské inspirace, Ariadnina nit a „didaktický stroj“ na cestě ke vzkř́ššenému Latiu) je výchozím bodem naší analýzy Komenského studie „Východisko ze školských labyrintů na volné prostranství čili mechanismus, zavedený do vyučování tak, aby se již nevázlo (tam, kde se vyučuje a učí), ale postupovalo vpřed““. ${ }^{23} \mathrm{Za}$ přispění komentáře Jana Patočky jsme mohli vidět, že užití metafor bloudění a následného stanovení cesty (metody), která by se stala východiskem pro nápravu či obnovení (instauratio) nejen vzdělanosti a vzdělávacích institucí, přinášejí evidenci o spřízněnosti základů reformátorských a zakladatelských misí Komenského a Bacona. Spř́zněnost sama však ještě nic nevypovídá o specifickém vyladění Komenského př́stupu k jazyku a rovinách, v nichž toto téma primárně kultivuje. V této souvislosti se nám ukázal význam nahlédnutí, že je hledáno východisko z labyrintů ve školách, které je velmi explicitně orientováno i na učení se jazykům.

\footnotetext{
20 F. Bacon, Nová Atlantida a Eseje, s. 23.

${ }^{21}$ F. Bacon, Nová Atlantida a Eseje, s. 40.

22 J. Kuncová, 'Příspěvek k pojetí jazyka u Francise Bacona a Jana Amose Komenského II', E-Logos (2016).
}

23 J. A. Komenský, „Východisko ze školských labyrintů na volné prostranství čili mechanismus, zavedený do vyučování tak, aby se již nevázlo (tam, kde se vyučuje a uči), ale postupovalo vpřed" in Scholarum reformator pansophicus (Comenii de educatione et scholis methodo naturali emendadis novissmae cogitationes) : Pansofický vychovatel (Komenského poslední myšlenky o reformě výchovy a škol príirozenou metodou), Praha: Státní pedagogické nakladatelství, 1956, s. 43 - 56. 
Při hledání cesty ven z labyrintů předkládá Komenský „dva důkazy stejného smyslu“, a to důkazy založené na př́kladech Ariadniny nitě a mechanického (didaktického) stroje, schopného pohybu.

Mohli jsme za vidět, že Ariadnina nit', pomocník na cestě z labyrintů, je ona správná a jednoduchá metoda, která nepřipouští svého potenciálně konce neberoucího matení. Komenského vize „,ideální metody“ je na některých místech ztotožňována s „přirozenou metodou“, a vyznačuje se jednoduchostí, prŕímostí a snadností. Před výkladem druhého důkazu, mechanického (didaktického) stroje, pak uvažuje o prostředcích dosažení univerzálních cílů vzdělání (kultivace) celé lidské přirozenosti a hlásí se nám tak dimenze, která je v jistých ohledech širší ve srovnání s tím, co můžeme vidět od Baconova textu. A právě pro námi sledovaný ohled pojetí jazyka je důležité vidět, že právě v tomto kontextu Komenský hovoří o misi pootevření náhledu do trojí knihy boží, knihy prŕrody, Písma a svědomí. Je tedy evidentní, že knihy boží nelze číst bez jazyka. Bez jazyka nelze kultivovat lidskou přirozenost, nelze porozumět „trojí knize boží.“ Usilujme se obnovit ono spojení „našeho jazyka“s jazykem trojí knihy boží, jazykem řádu stvoření. Když takové určení přijmeme, můžeme zahlédnout specifickou jednotu a diferenci misí sledovaných myslitelů.

V dalším kroku jsme se pokusili zrekonstruovat onen druhým důkaz, druhou cestu ze školských labyrintů, a to didaktický, mechanický stroj. Byli jsme svědky Komenského volání po tom, aby metoda lidského vzdělávání byla mechanická, jistá, aby nic, čemu se bude ,vyučovati, učiti a dělati, nemohlo býti bez úspěchu, stejně jako dobře řízené hodiny, vůz, lod'“, tady jako každý uměle k pohybu vytvořený stroj. Nemůže zde nepřipomenout, že účel mechanické metody ,je trojí: věděti, dělati, mluviti“, čili všechno „pravdivě znáti, moci vše dobré správně dělati a co je nutné, sdělovati bližnímu.“ Pro naše srovnání s Baconem je „teorie didaktického stroje“ význačná právě tím, jak se Komenský dotýká tématu jazyka právě z té stránky, která není primárně nesena představou kultivace lidské přirozenosti náhledem do „trojí knihy boží“, tedy představě o jazyku v jistém ohledu primárně fundovaným teologicky. Jazyk zde totiž vystupuje právě v kontextu se specifickým druhem jednání a svého druhu činem. Komenský výslovně hovoří o ,jazyce či schopnosti mluvit“ jako o takovém druhu jednání, které neustále přihlíží $\mathrm{k}$ věcem, ,k jejichž označování se ho používá, aby význam toho, co má být vyjádřeno, byl jasný a průhledný, nikoli jiný.“ Výklad didaktického stroje vyúst'uje v představu reformy školské soustavy, v otevření škol trojího druhu, v nichž by mohl tento stroj ,podat plný výkon“. Není jistě pochyb o tom, že Baconovo pojetí metody, i v tom, jak ji můžeme vidět od Nové Atlantis, bylo pro Komenského obtížně zpochybnitelným zdrojem inspirace, nicméně Komenského provedení je originální a jen obtížně můžeme z Baconových vizí odvodit misi Vzkř̌íšeného Latia.

Pro porovnání Baconova a Komenského pojetí jazyka tak má zásadní význam analýza, kterou jsme nastínili v druhé části článku o Komenském (2.2 Vzkř́šené Latium). Mohli jsme vidět, že Vzkříšené Latium ${ }^{24}$ představuje pro náš účel vpravdě exemplární „př́ípadovou studii“ nechávající vystoupit Komenského vizi uplatnění oné přirozené metody (Ariadniny nitě) a didaktického stroje $v$ její specifičnosti a velmi čisté podobě, kdy je dovedena až do velmi praktické a dobově zakotvené konkrétnosti jeho úsilí o ustavení nového typu školy, koleje internátu obnovující a oživující jazyk latinský, jazyk jako médium zprostředkující a vủbec otevírající náš př́stup $\mathrm{k}$ pokladům moudrosti. Navržena je tak instituce zcela nového typu, prostá jakéhokoli prázdného formalismu či školometství, představující „obec v malém“, kde se řeči učí „užíváním a zvykem“, kde se tím dosahuje „,dokonalé znalosti celého latinského jazyka“, a důležité je, že se to děje ,zároveň s celým souborem věcí nezbytných k životu“. Zde 
se Komenský ukazuje od své mise „učitele národů“, reformátora školských soustav a vzdělání, ale i v té dimenzi, která dává nahlédnout rozdílu s Baconovou vizí Šalamounova domu či Koleje šesti dnů. Až s didaktickou konkrétností vyžaduje, aby se „vyučovalo jazyku zároveň s věcmi“. Jeho ,přirozená metoda“ směřuje $\mathrm{k}$ tomu, aby „,vše plynulo samo sebou, aby se nezasahovalo do věcí násilím“. A není pak divu, že taková výchova nutně s sebou nese „obrovský a jinde neslýchaný zisk“, žáci totiž konají „ustavičná cvičeni'“ a jsou soustavně uváděni do celé palety oblastí, jejichž ovládnutí diktuje životní zkušenost. Pro námi sledované téma jazyk je podstatné, že ono uvádění do celé palety oblastí znamená nastoupení cesty k „znáti, spravovati, ovládati terminologii a vyjadřování“. Vždyt' právě cvikem „,pravým a hravým“ lze ovládnout i gramatiku, lidé se „procházejí, spolu hovoří, spolu si hrají a těší se z věcí, z jazyka a ze sebe“. V neposlední řadě Komenský chápe Vzkřriššené Latium jako svého druhu vynález, v jistém smyslu tak doznává Baconovský experimentální duch specifického zpř́ítomnění, a není tedy divu, že usiluje o jeho uplatnění/ověření v praxi a celou polovinu své studie věnuje otázkám jeho realizace, pro niž si zvolil město Amsterodam. ${ }^{25}$ Kultivace pojetí jazyka v jeho vázanosti či dialogu s věcmi, životem, společenstvím i se sebou samými nabývá ve Vzkřrišeném Latiu svébytné, vrcholné a zakladatelské podoby, která s sebou nepochybně nese nadčasové poselství. Ve 3. části článku (Sheridanovo „Nové Latium“ v Dublinu) přineseme př́ípadovou studii o tom, že Komenského idea Nového Latia doznala specifické realizační podoby v Dublinu první třetiny 18. století, i když založení Sheridanovy školy zřejmě nemůže být chápáno jako její prostá aplikace a pro explicitní inspiraci Novým Latiem nám doposud schází př́má rukopisná evidence.

\subsection{Swiftova idea akademie pro reformu a nápravu anglického jazyka}

V létě roku 1711 navštívil Jonathan Swift Oxford a představil zde svůj projekt „společnosti nebo akademie napravující a stabilizující podobu našeho jazyka, aby neustále nepodléhal konce neberoucím proměnám“. ${ }^{26}$ Nelze než souhlasit s Irvinem Ehrenpreisem, že tato idea nebyla ničím podstatně novým, nebot' v Anglii 17. století rozhodně nebylo cizí přesvědčení, že anglický jazyk musí doznat regulace, abychom zabránili jeho úpadku, a vznikla celá řada plánů na jeho ochranu, obnovení či reformu. ${ }^{27}$ Již Thomas Sprat ve své History of Royal Society of London z roku 1767 doporučuje založení akademie pro zdokonalení a uchování jazyka a pro námi sledované téma je důležité si připomenout, že ke vzniku Královské společnosti již ve 40. letech 17. století se odehrávající debaty učenců právě o uplatnění Baconových ideálů vědy a jejího provozu, jak byly slavně nastíněny např. právě v jeho Nové Atlantidě. Není však překvapením, že při výkladu Swiftovy ideje akademie pro reformu a nápravu anglického jazyka nenalezneme explicitní textovou evidenci, která by nesla svědectví o př́mé inspiraci Baconem. Jeho odkaz je na počátku 18. století v Anglii již něčím, co je s jistou samožrejmostí učenci přijímáno a není zde potřeba legitimizovat každý projekt na něm založený odkazem na jeho autoritu. Ve svém Eseji o moderním vzdělání však na Bacona explicitně odkazuje, ${ }^{28} \mathrm{i}$ když je evidence o jisté míře obeznámenosti s dílem Francise Bacona, než přímé svědectví o zdroji inspirace pro založení akademie.

\footnotetext{
25 Přes veškerou snahu se Komenskému Nové Latium v Amsterodamu založit nepodařilo.

${ }^{26}$ I. Ehrenpreis, Swift: The Man, his Works, And the Age, Volume 2, Methuen: 1982 (1967), s. 543.

27 I. Ehrenpreis, Swift: The Man, his Works, And the Age, Volume 2, Methuen: 1982 (1967), s. 542 543.

28 J. Swift, 'An Essay on Modern Education', in The Works of Jonathan Swift, D.D. by Sir Walter Scott, Second edition, Volume IX, Edinburgh, 1824, s. 163.
} 
Idea akademie pro reformu a nápravu jazyka je podána $\mathrm{v}$ pamfletu, jehož celý titul zní: 'A Proposal for Correcting, Improving, and Ascertaining, the English Tongue, in A Letter to the Most Honourable Robert, Earl of Oxford and Mortimer, Lord High Treasurer of Great Britain' ${ }^{29}$ Prvního vydání se dočkal v květnu 1712 a od celého titulu viděno, měl formu dopisu adresovaného ( $\mathrm{z}$ dnešního pohledu) ministrovi financí, jako politické autoritě a muži moci, $\mathrm{v}$ jehož silách je akademii zaštítit a v neposlední řadě projekt podpořit státními financemi. Alespoň stručnou rekonstrukci Swiftovy ideje a projektu provedeme jak z vlastního primárního textu, tak přihlédneme ke kritickému Ehrenpreisovu výkladu. ${ }^{30}$

Pamflet se sestává ze tří částí a první z nich nemůže začít jinak než zprávou o stavu anglického jazyka. Swift se pokouší uplatnit historický přistup a poukázat na to, že angličtina utrpěla v důsledku tlaku vnějších vlivů, a to zejména v důsledku vojenských invazí a kontaminací francouzštinou. Sice připouští, že změnám podléhají všechny jazyky, ale zároveň se domnívá, že konce neberoucí a rychlé změny jazyka nejsou nevyhnutelné. Znečistění angličtiny neologismy, staženými tvary, slangem, zkratkami a spodobou hlásek (asimilací) narůstá od vlády Karla I. (skončena 1649). Líčení stavu anglického jazyka je místy podáno s nádechem dramatičnosti: „Vaše lordstvo, jménem všech vzdělaných a kultivovaných př́islušníků národa vznáším stížnost ... že náš jazyk je nesmírně nedokonalý; že jeho každodenní pokroky nejsou v žádném př́ípadě souměřitelné s mírou jeho každodenního úpadku; že nárokovatelé na jeho zdokonalení a zjemnění obvykle znásobili míru jeho zneužití a výskytu prohřešků, proti nimž není imunní žádná část gramatiky. “31 Je zde však ještě jeden př́znak úpadku jazyka, který volá po nápravě, a to zmnožení způsobů výslovnosti. ${ }^{32}$ Jednou z prŕčin ,zohaveni““ (maiming) anglického jazyka je ,komická představa, .... že musíme slova psát přesně tak, jak je vyslovujeme. ... S odlišnou výslovností se můžeme setkat nejen v některých městech a hrabstvích, ale dokonce zde v Londýně je jiná výslovnost užívána u dvora, jiná ve městě (city), a na třetí způsob výslovnosti narážíme na předměstích. " ${ }^{33}$ Swift se nám tak ukazuje jako poměrně systematický pozorovatel a sběratel jazykových jevů, a s jistou nadsázkou snad můžeme říci, že toto pozorování a sbírání jevů rozhodně není cizí přístupu baconovsky orientované zkušenostní (či „experimental“) vědy. Při pozorném čtení pamfletu nám však neunikne, že ministra financí a další čtenáře autor „ušetří“ hlubšího ponoru do sféry teorie jazyka $^{34}$ a bez velkého „teoretizování“ přistoupí k návrhu na založení akademie či učené společnosti pro reformu anglického jazyka. Swiftův návrh či projekt si představíme formou citací výběru ze tří stěžejních pasáží (paragrafü) pamfletu (číslování - J. K.), které následně shrneme a doplníme komentářem.

(1) „In order to reform our language, I concieve, my lord, that a free judicious choice should be made of such persons, as are generally allowed to be best qualified for such a work, without any regard to quality, party, or profession. These, to a certain number at least, should assemble

29 J. Swift, 'A Proposal for Correcting, Improving, and Ascertaining, the English Tongue', in The Works of Jonathan Swift, D.D. by Sir Walter Scott, Second edition, Volume IX, Edinburgh, 1824, s. 137 - 159.

30 I. Ehrenpreis, Swift: The Man, his Works, And the Age, Volume 2, Methuen: 1982 (1967), s. 542 549.

31 J. Swift, 'A Proposal for Correcting, Improving, and Ascertaining, the English Tongue', s. 140.

32 Je s podivem, že právě tomuto ohledu se $v$ Ehrenpreisově interpretaci Swiftova projektu nápravy jazyka nedostalo zasloužené pozornosti.

33 J. Swift, 'A Proposal for Correcting, Improving, and Ascertaining, the English Tongue', s. 148.

34 Jedna z mála jazykovědných publikací o Swiftovi je věnována jeho príspěvku do diskuse o anglické výslovnosti. Srov.: J. H. Neumann, 'Jonathan Swift and English Pronunciation', in Quarterly Journal of Speech, Volume 28, 1942 - Issue 2, s. 198 - 201. 
at some appointed time and place, and fix on rules, by which they design to proceed. What methods they will take, is not for me to prescribe. ${ }^{\text {"35 }}$

V prvním kroku návrhu můžeme vidět, že výběr členů akademie by měl být vázán čistě na jejich kompetenci pro reformní misi akademie, v tom smyslu uvážlivý, ale i svobodný, nezávislý na společenském postavení, politickém postoji či profesi kandidátů. První úkol akademiků bude dostavit se na „ustavující shromážděni“", které stanoví pravidla, jimiž se akademie bude řídit. Swift si nečiní nárok na to předepisovat akademikům postupy a metody, které budou používat.

(2) „The persons who are to undertake this work, will have the example of the French before them, to imitate where these have proceeded right, and to avoid their mistakes. Beside the grammar part, wherein we are allowed to be very defective, they will observe many gross improprieties, which, however authorized by practice, and grown familiar, ought to be discarded. They will find many words that deserve to be utterly thrown out of our language, many more corrected, and perhaps not a few long since antiquated, which ought to be restored on account of their energy and sound." ${ }^{\text {3 } 6}$

V úvodu druhého kroku Swift staví před akademiky vzor Francouzské akademie, která se mu zřejmě vzhledem k povaze úkolu akademie pro nápravu anglického jazyka jeví přiměřenější, než „model“ místní Royal Society of London, žádné výslovné důvody pro její preferenci však neuvádí, pouze upřesňuje, aby akademici převzali z Francouzské akademie to správné, ale vystř́íhali se jejich omylů. V další části paragrafu již nastiňuje „výzkumné cíle“ instituce. Jistě, identifikace chyb, kterých se dopouštíme $\mathrm{v}$ gramatice nebude obtížným úkolem a mise akademie se tím však rozhodně nevyčerpává. Akademici musí sledovat četné př́ípady zcela nevhodného užití jazyka, které jsou sice legitimovány praxí a zdomácněly, nicméně je zapotřebí se jich vystříhat. Odhalí také některá slova, jež by měla být ze „slovníku anglického jazyka“ vyškrtnuta, mnohem více slov by pak mělo doznat korekce, některá „zastaralá“ slova by pak měla být oživena a navrácena do ,jazykového provozu“ na základě svého (významového?) potenciálu a vyznění (,,sound and energy“).

(3) „But what I have most at heart, is, that some method should be thought on for ascertaining and fixing our language for ever, after such alterations are made in it as shall be thought requisite. For I am of opinion, it is better a language should not be wholly perfect, than that it should be perpetually changing; and we must give over at one time, or at lenght infallibly change for the worse ..." 37

Ve třetím a závěrečném kroku nám Swift odhaluje to, co je proň rozhodující pro dosažení hlavního cíle či poslání Akademie. Musíme najít postup či metodu, jejíž pomocí bychom dosáhli konečného a definitivního (,for ever") zajištění a stabilizace (,,ascertaining and fixing“) anglického jazyka, a to poté, kdy akademici jazyk vhodně reformují. $Z$ finále paragrafu snad můžeme uvidět, že dosažení „naprosto dokonalého“ stavu anglického jazyka není splnitelným cílem. Swiftova preference je zřejmá, lepší je mít jazyk s deficiencí dokonalosti, než mít jazyk neustále se proměňující.

Swiftův návrh akademie či společnosti pro reformu anglického jazyka nebyl př́znivě přijat ani ministrem financí, morální ani finanční podpora se nekonala, ani nezískal výraznější podporu mezi učenci prvních desetiletí 18. století. S odstupem desetiletí kritiku Swiftova návrhu slavně zformuloval Dr. Samuel Johnson: „... written without much knowledge of the general nature

\footnotetext{
35 J. Swift, 'A Proposal for Correcting, Improving, and Ascertaining, the English Tongue', s. 151

${ }^{36} \mathrm{~J}$. Swift, 'A Proposal for Correcting, Improving, and Ascertaining, the English Tongue', s. 151

37 J. Swift, 'A Proposal for Correcting, Improving, and Ascertaining, the English Tongue', s. 151 - 152.
} 
of language, and without any accurate inquiry into the history of other tongues. The certainty and stability which, contrary to all experience, Swift thinks attainable, he proposes to secure by instituting an academy; the decrees of which every man would have been willing, and many would have been proud, to disobey, and which, being renewed by successive elections, would, in a short time, have differed from itself." 38 S Johnsonovou kritikou lze jistě v mnoha ohledech souhlasit, baconovsky laděná rétorika a idea akademie bez výzkumné práce orientované důkladnějším teoretickým založením není ještě zárukou ničeho. Na druhé straně, Swiftovy myšlenky např. o anglické výslovnosti se dočkaly nečekaného ohlasu po jeho návratu do Dublinu a inspirovaly mladého Thomase Sheridana, od 50. let 18. století největšího propagátora správné výslovnosti ve Velké Británii, autora A General Dictionary of the English Language a prvního editora The Works of the Rev. Jonathan Swift.

\subsection{Sheridanovo „Nové Latium“ v Dublinu}

V kapitole 3.1 jsme shrnuli, že Komenského „Nové Latium“ bylo zamýšleno jako instituce zcela nového typu, prostá prázdného formalismu či školometství, představující „obec v malém“, kde se řeči učí „užíváním a zvykem“, kde se tím dosahuje „dokonalé znalosti celého latinského jazyka“, a důležité je, že se to děje „zároveň s celým souborem věcí nezbytných k životu“. Komenského plány na založení latinské koleje v Holandsku nebyly realizovány, to však nic nemění na síle a inspirativnosti jeho idejí o reformě školských soustav a výuky jazyků. Jeho představa, že právě cvikem „,pravým a hravým“ lze ovládnout i gramatiku, žáci za účasti učitelů se v koleji ,procházejí, spolu hovoří, spolu si hrají a těší se z věcí, z jazyka a ze sebe“, jen obtížně může zestárnout a v závěrečné kapitole studie jsme před sebe postavili úkol, ukázat si alespoň základní horizonty její realizační podoby, jaké překvapivě nabyla v Dublinu v poslední třetině druhého desetiletí 18. století, v latinské akademii Thomase Sheridana (16871738). Předcházející kapitolu jsme zakončili nástinem kritiky Swiftova návrhu na zrrízení akademie pro reformu anglického jazyka. Nyní se nám Swift ukáže i z jiné stránky, jako podporovatel reformované školy vyučující jazykům v intencích Komenského ideálů, i když explicitní odkaz na nějaké Komenského dílo ani u Swifta, ani u Sheridana předložit nemůžeme. Oporu nezískáme ani z katalogu vzácných knih Trinity College Dublin, kde Sheridan studoval. Není zřejmé, zda počátkem 18. století zde byla Komenského díla dostupná.

Začátek učitelská kariéry Thomase Sheridana je datován do roku 1713, po ukončení prvního stupně studií na Trinity College Dublin (1711 BA, 1714 MA, doktorská studia 1724 a 1726). Záhy uskutečňuje představu o nové akademii založené na latinské akademii, která však bude klást důraz na „speech training“, oživení latinského jazyka a živý anglický jazyk včetně důrazu na výslovnost. Traduje se blíže nedatovaný rozhovor mezi Sheridanem a Swiftem, který snad může být vysvětlením pro Sheridanův koncept akademie akcentující orientaci na mluvený jazyk: ,... when Sheridan was a student at Trinity College, Dublin, Swift had asked him what he was learning there. 'When I told the course of reading I was put into, he asked me, 'Do they teach you English? Do they teach you how to speak?, 'No.' Then he said, 'They teach you nothing. ${ }^{39}$ V roce 1714 vydává Sheridan inspirovaný potřebami žáků své akademie v Dublinu knihu An Easy Introduction of Grammar in English for the Understanding of Latin Tongue, kterou komentoval jako výsledek své snahy uchránit mladé chlapce před „dřinou a problémy

38 Citováno podle poznámky in J. Swift, 'A Proposal for Correcting, Improving, and Ascertaining, the English Tongue', s. 137.

${ }^{39}$ R. E. Ward, An Encyklopedia of Irish Schools, 1500 - 1800, Lampeter : Edwin Mellen Press, 1995, s. $62-63$. 
(„,miserable toil and trouble“), které provázejí četbu latinského textu““ ${ }^{40} \mathrm{~V}$ předmluvě ke knize ostře odsuzuje učení latině prostřednictvím „spousty pravidel“ („,heap of rules“), tupého memorování a trestání. ${ }^{41}$ V témže roce vydává vlastní zdokonalenou verzi Lilyho Royal Grammar, v níž pro názornost a lepší pochopení používá anglické verše a zavádí různé mnemotechnické pomůcky. ${ }^{42}$ James Wooley nám odhaluje další pozoruhodnou rovinu Sheridanovy akademie: „In the cultural life of Dublin, Sheridan's school was particularly noted for its performances of plays, usually Latin, Greek, or Shakespearean. It was part of his pedagogical method for the boys 'to act plays first and understand them after.' ${ }^{\prime \prime 43}$ Můžeme tedy vidět, že Sheridan pokročilým způsobem zpřítomňuje Komenského ideál ,školy hrou“ při výuce jazyků, a to prostřednictvím divadelních představení v řeckém, latinském a anglickém jazyce.

Swiftovo tvrzení o Thomasi Sheridanovi, že je „doubtless the best instructor of youth in these kingdoms“, nejlepším učitelem, který působí ve Velké Británii, se opírá o Swiftovu př́ímou zkušenost $\mathrm{s}$ latinskou akademií, ale $\mathrm{v}$ jistém smyslu vyjadřuje i souznění $\mathrm{s}$ její ideou a praktickým provedením. On sám je považován za největšího př́tele Thomase Sheridana a nejvýznamnějšího propagátora jeho školy. Swiftovu podporu věci Sheridanovy školy plasticky popisuje Watkins: ,Swift was indefatigable in his endeavors to promote the flourishing state of his school. He recommended him to all as the ablest master of his age; and published a copy of his Latin verses in his praise as such; he descended even at times to act as his usher; and frequently attended at school to hear a class. When the doctor (Thomas Sheridan - J. K.) was ill, or absent in the country, he supplied his place, and was always one of the examiners at the public examinations. Such attention paid to (it) by one of Swift's high character could not fail of raising the reputation of the school; and accordingly, it far exceeded any other seminary known in Ireland.“

Snad si můžeme dovolit zformulovat závěr, který koriguje naše předběžné představy o zpř́itomnění Bacona a Komenského v myšlení Jonathana Swifta o jazyku. Prvotní představa spojovaná se Swiftovým návrhem reformy anglického jazyka cestou ustavení akademie či učené společnosti nás vedla k předmínění, že v návrhu, ideji akademie, získáme evidenci o téměř explicitní inspiraci ideálem vědy baconovské ražby. Ideál učené společnosti jsme mohli zahlédnout, náznaky pozorování a sběru jazykových jevů jsou v návrhu rovněž vykazatelné. Přesto však samotné provedení můžeme k Baconovi vztáhnout spíše jen v rovině rétorické a rovině dobově již samozřejmých institucionálních představ o organizaci vědy. Po naší cestě do akademie postavené jako latinská akademie Thomase Sheridana v Dublinu můžeme vidět, že představuje specifické zpř́tomnění alespoň některých ohledů Komenského „Nového Latia“, silněji pak tvůrčí zpř́ítomnění ideálu „školy hrou“ při výuce jazyků i dalších pedagogických principů. Swiftova blízkost Sheridanově akademii není něčím nahodilým, souznění není jen formální, ale zakládá se na blízkosti v pojetí jazyka a cest jeho kultivace. Nabízí se možnost nového pohledu na doposud jen okrajově tematizovanou rovinu Swiftova myslitelského odkazu, která je úzce spjata s misí Sheridanovy akademie. V jistých ohledech se nám tak může

${ }^{40}$ R. E. Ward, An Encyklopedia of Irish Schools, 1500 - 1800, Lampeter : Edwin Mellen Press, 1995, s. 89.

41 T. Sheridan, An Easy Introduction of Grammar in English for the Understanding of the Latin Tongue, Dublin, 1714, Preface.

42 W. E. Meyer, , 'Thomas Sheridan (1687 - 1738)', Oxford Dictionary of National Biography, Volume 50, Oxford: Oxford University Press, 2004, s. 305.

${ }^{43}$ R. E. Ward, An Encyklopedia of Irish Schools, 1500 - 1800, Lampeter : Edwin Mellen Press, 1995, s. 90 . 
ukázat jako myslitel daleko bližší tradici Komenského, než jsme před cestou do Dublinu mohli usuzovat.

\section{Seznam použitých zdrojů}

P. Ayres, Classical Culture and the Idea of Rome in Eighteenth-Century England, Cambridge: Cambridge University Press, 2009 (1997).

F. Bacon, Nová Atlantida a Eseje, Praha: Mladá Fronta, 1980 (překl. A. Bejblík).

F. Bacon, The New Atlantis:or a Plan of a Society for the Promotion of Knowledge in The Philosophical Works of Francis Bacon, In Three Volumes, Vol. I., ed. P. Shaw, London: Printed for J. J. and P. Knapton, 1733, s. $278-300$.

F. Bacon, Nové organon, Praha: Česká akademie věd a umění, 1922 (překl. Č. Stehlík a A. Stejskal).

F. Bacon, Nové organon, Praha: Svoboda, 1990 (překl. M. Zůna).

P. Harrison, The Bible, Protestantism, and the Rise of Natural Sciences, Cambridge: Cambridge University Press, 1998.

I. Ehrenpreis, Swift: The Man, his Works, And the Age, Volume 2, Methuen: 1967.

I. Ehrenpreis, Swift: The Man, his Works, And the Age, Volume 3, Methuen: 1983.

W. H. Epstein, John Cleland: Images of Life: A Biography of the Author of a Woman of Pleasure (Fanny Hill), New York and London: Columbia University Press, 1974.

P. Harrison, The Fall of Man and the Foundations of Science, Cambridge: Cambridge University Press, 2007.

J. A. Komenský, „E scholasticis labyrinthis exitus in planum. Sive Machina didactica mechanice constructa: ad non haerendum amplius (in docendi et discendi muniis) sed progrediendum“ in Scholarum reformator pansophicus (Comenii de educatione et scholis methodo naturali emendadis novissmae cogitationes) : Pansofický vychovatel (Komenského poslední myšlenky o reformě výchovy a škol přirozenou metodou), Praha: Státní pedagogické nakladatelství, 1956, s. 5 - 17.

J. A. Komenský, „Východisko ze školských labyrintů na volné prostranství čili mechanismus, zavedený do vyučování tak, aby se již nevázlo (tam, kde se vyučuje a učí), ale postupovalo vpřed“ in Scholarum reformator pansophicus (Comenii de educatione et scholis methodo naturali emendadis novissmae cogitationes) : Pansofický vychovatel (Komenského poslední myšlenky o reformě výchovy a škol přirozenou metodou), Praha: Státní pedagogické nakladatelství, 1956, s. 43 - 56.

J. A. Komenský, „Paradisus juventuti christianae reducendus sive optimus scholarum status, ad primae paradisiacae scholae ideam delineatus" in Scholarum reformator pansophicus (Comenii de educatione et scholis methodo naturali emendadis novissmae cogitationes) : Pansofický vychovatel (Komenského poslední myšlenky o reformě výchovy a škol přirozenou metodou), Praha: Státní pedagogické nakladatelství, 1956, s. $29-39$.

J. A. Komenský, „Jak mládeži křest’anské navrátit ráj čili O nejlepším stavu škol podle ideje rajské“ in Scholarum reformator pansophicus (Comenii de educatione et scholis methodo naturali emendadis novissmae cogitationes) : Pansofický vychovatel (Komenského poslední myšlenky o reformě výchovy a škol přirozenou metodou), Praha: Státní pedagogické nakladatelství, 1956, s. 73 - 84.

J. A. Komenský, Labyrint světa a ráj srdce, Praha: Odeon, 1984.

J. A. Komenský, „Latium redivivum. Hoc est. De forma erigendi latissimi collegii ceu novae romanae civitatulae, ubi latina lingva usu et consevetudine ut olim, meliús tamen qvam olim, addiscatur“ in Scholarum reformator pansophicus (Comenii de educatione et scholis methodo naturali emendadis novissmae cogitationes) : Pansofický vychovatel (Komenského poslední myšlenky o reformě výchovy a škol přirozenou metodou), Praha: Státní pedagogické nakladatelství, 1956, s. 18 - 28.

J. A. Komenský, „Vzkř̌íšené Latium, to jest O způsobu, jak zř́iditi úplně latinskou kolej jakoby novou malou obec rímskou, kde by se znalosti latinského jazyka nabývalo užíváním a zvykem jako za starých dob, ale lépe než za starých dob“ in Scholarum reformator pansophicus (Comenii de educatione et scholis methodo naturali emendadis novissmae cogitationes) : Pansofický vychovatel (Komenského poslední myšlenky o reformě výchovy a škol přirozenou metodou), Praha: Státní pedagogické nakladatelství, 1956, s. 57 - 69. 
J. Kuncová, 'Příspěvek k pojetí jazyka u Francise Bacona a Jana Amose Komenského I', E-Logos (2013).

J. Kuncová, 'Příspěvek k pojetí jazyka u Francise Bacona a Jana Amose Komenského II', E-Logos (2016).

W. E. Meyer, , 'Thomas Sheridan (1687 - 1738)', Oxford Dictionary of National Biography, Volume 50, Oxford: Oxford University Press, 2004, pp. $305-306$.

A. Molnár a N. Rejchrtová, Jan Amos Komenský o sobě, Praha: Odeon, 1987.

J. Popelová, Jana Amose Komenského cesta k všenápravě, Praha: Státní pedagogické nakladatelství, 1956.

J. H. Neumann, 'Jonathan Swift and English Pronunciation', in Quarterly Journal of Speech, Volume 28, 1942 Issue 2, pp. 198 - 201 (Published online: 05 June 2009, https://doi.org/10.1080/00335634209380757).

J. Patočka, „O pozdních pedagogických spisech Komenského“ in Scholarum reformator pansophicus (Comenii de educatione et scholis methodo naturali emendadis novissmae cogitationes) : Pansofický vychovatel (Komenského poslední myšlenky o reformě výchovy a škol přirozenou metodou), Praha: Státní pedagogické nakladatelství, 1956, s. 85.

Scholarum reformator pansophicus (Comenii de educatione et scholis methodo naturali emendadis novissmae cogitationes) : Pansofický vychovatel (Komenského poslední myšlenky o reformě výchovy a škol přirozenou metodou), Praha: Státní pedagogické nakladatelství, 1956.

T. Sheridan, An Easy Introduction of Grammar in English for the Understanding of the Latin Tongue, Dublin, 1714.

J. Swift, 'Character of Dr. Sheridan', in The Works of Jonathan Swift, D.D. by Sir Walter Scott, Second edition, Volume IX, Edinburgh, 1824, s. 310 - 313.

J. Swift, 'The History of the Second Solomon', in The Works of Jonathan Swift, D.D. by Sir Walter Scott, Second edition, Volume IX, Edinburgh, 1824, s. 314 - 321.

J. Swift, 'A Proposal for Correcting, Improving, and Ascertaining, the English Tongue', in The Works of Jonathan Swift, D.D. by Sir Walter Scott, Second edition, Volume IX, Edinburgh, 1824, s. 137 - 159.

J. Swift, 'An Essay on Modern Education', in The Works of Jonathan Swift, D.D. by Sir Walter Scott, Second edition, Volume IX, Edinburgh, 1824, s. 160 - 170.

The Works of Jonathan Swift, D.D. by Sir Walter Scott, Second edition, Volume IX, Edinburgh, 1824.

The Works of the Rev. Jonathan Swift, D.D., Volume I, London, 1801.

The Works of the Rev. Jonathan Swift, D.D., Volume XIX, London, 1801.

R. E. Ward, An Encyklopedia of Irish Schools, 1500 - 1800, Lampeter : Edwin Mellen Press, 1995. 